\title{
IMPLEMENTASI MODEL PEMBELAJARAN KOOPERATIF JIGSAW OLEH GURU PAK UNTUK MENINGKATKAN KREATIVITAS BELAJAR SISWA KELAS VII SMP NEGERI 3 SIPOHOLON KECAMATAN SIPOHOLON T.P 2017/2018
}

\author{
Tianggur Medi Napitupulu \\ Institut Agama Kristen Negeri Tarutung \\ Email: tianggurnapitupulu74@yahoo.co.id
}

\begin{abstract}
Abstrak - Penelitian ini bertujuan untuk mengetahui bagaimana Implementasi Model Pembelajaran Kooperatif Jigsaw oleh Guru PAK Untuk Meningkatkan Kreativitas Belajar Siswa kelas VII SMP Negeri 3 Sipoholon. Subjek dalam penelitian ini adalah kelas VII yang berjumlah 23 siswa, dan objek penelitian ini adalah model pembelajaran kooperatif jigsaw. Dalam pengambilan data, teknik yang digunakan adalah lembar observasi. Sedangkan teknik analisis data dengan reduksi data, paparan data, dan penarikan kesimpulan. Dari data hasil observasi menunjukkan bahwa kreativitas belajar siswa mengalami peningkatan pada siklus I kreativitas belajar siswa mencapai $26,96 \%$, pada siklus II kreativitas belajar siswa mencapai $64,35 \%$ mengalami peningkatan $37,39 \%$, dan pada siklus III kreativitas belajar siswa mencapai $80,87 \%$ mengalami peningkatan sebesar $16,52 \%$. Untuk penerapan model pembelajaran jigsaw yang diterapkan oleh guru PAK mengalami peningkatan. Pada siklus I diterapkan 64\% dari yang diharapkan dan berada pada kategori cukup. Pada siklus II diterapkan $80 \%$ dari yang diharapkan dan berada pada kategori kuat. Pada siklus III diterapkan $96 \%$ dari yang diharapkan dan berada pada kategori kuat. Berdasarkan penelitian yang dilakukan dapat bahwa penerapan model pembelajaran kooperatif jigsaw oleh guru PAK dapat meningkatkan kreativitas belajar Pendidikan Agama Kristen di kelas VII SMP Negeri Negeri 3 Sipoholon, Kecamatan Sipoholon T.P 2017/2018 dan mencapai 70-90\% dari yang diharapkan.
\end{abstract}

Kata kunci : Model pembelajaran Koperatif jigsaw, Kreatifitas Belajar Siswa

\begin{abstract}
This study was aimed to investigate the implementation of Jigsaw Cooperative Learning Model applied by Christian religious education teachers in improving grade 7 students' learning creativity at SMP 3 Sipoholon. The participants were 23 junior high school students. Observation sheet was used to collect data. The following data analysis was conducted, namely data reduction, data exposure, and conclusion. The result of study revealed that students' learning creativity has increased in the first cycle, reached 26.96\%. It was applied 64\% of the expected and was in the sufficient category. In the second cycle, students' learning creativity reached $64.35 \%$ and had increased $37.39 \%$. it was applied $80 \%$ of the expected and was in the strong category. Finally, students' learning creativity in the third cycle reached $80,87 \%$ and had increased $16.52 \%$. It was applied $96 \%$ of the expected and was in the stronger category. Therefore, it can be concluded that the implementation of the Jigsaw Cooperative Learning Model can improve the creativity of Christian religious education learning among junior high school students.
\end{abstract}

Keywords: Cooperative jigsaw learning model; student learning creativity; students

\section{PENDAHULUAN}

Kreativitas belajar siswa sangat penting dan harus dimiliki dalam mengikuti proses pembelajaran karena kreativitas adalah hasil belajar dalam kecakapan kognitif yang dapat dipelajari melalui proses belajar mengajar. Siswa dikatakan kreatif apabila mampu melakukan sesuatu yang menghasilkan sebuah kegiatan baru yang diperoleh dari hasil berpikir kreatif dengan mewujudkannya dalam bentuk sebuah hasil karya baru.

Banyak resep untuk menciptakan suasana belajar yang kondusif, yang dapat mengembangkan aktivitas dan kreativitas belajar secara optimal sesuai dengan kemampuan masing-masing siswa salah satunya adalah guru menerapkan metode pembelajaran kooperatif. Menurut Nurulhayati (2002:25) dalam Rusman 
(2010:203) menuliskan bahwa pembelajaran kooperatif adalah strategi pembelajaran yang melibatkan partisipasi siswa dalam satu kelompok kecil untuk saling berinteraksi. Ditambahkan oleh Rusman (2010:202) bahwa pembelajaran kooperatif (cooperative learning) merupakan bentuk pembelajaran dengan cara siswa belajar dan bekerja dalam kelompok-kelompok kecil secara kolaboratif yang anggotanya terdiri dari empat sampai enam orang dengan struktur kelompok yang bersifat heterogen.

Dalam sistem belajar yang kooperatif, siswa belajar bekerjasama dengan anggota lainnya. Dalam model ini siswa mempunyai dua tanggungjawab, yaitu mereka belajar untuk dirinya sendiri dan membantu sesama anggota kelompok untuk belajar. Siswa belajar bersama dalam sebuah kelompok kecil dan mereka dapat melakukannya. Demikian halnya dalam kegiatan belajar Pendidikan Agama Kristen, model pembelajaran kooperatif ini sangat bagus untuk diterapkan, karena penerapan model pembelajaran kooperatif memiliki asumsi bahwa pengetahuan dibentuk dan dibangun melalui kerjasama dalam aktivitas belajar, termasuk menyelidiki, berdiskusi, memahami dan memecahkan masalah. Belajar dari sesamanya juga melandasi model pembelajaran kooperatif, seperti yang ditegaskan dalam kitab Amsal 27:17: "Besi menajamkan besi, orang menajamkan sesamanya." Artinya dengan adanya kerjasama yang baik antara siswa dengan siswa dan antara siswa dengan guru dalam berdiskusi, berbagi pengetahuan maka akan dapat meningkatkan pemahaman siswa tentang materi Pendidikan Agama Kristen yang diajarkan di sekolah.

Pembelajaran kooperatif tidak sama dengan sekedar belajar dalam kelompok. Ada unsur dasar pembelajaran kooperatif yang membedakan dengan pembelajaran kelompok yang dilakukan asalasalan. Pelaksanaan prinsip dasar pokok sistem pembelajaran kooperatif dengan benar akan memungkinkan guru mengelola kelas dengan lebih efektif. Dalam pelaksanaan kooperatif, proses pembelajaran tidak harus belajar dari guru kepada siswa, tetapi siswa dapat saling membelajarkan sesama siswa lainnya.

Menurut Rusman (2010:213225) ada beberapa model-model pembelajaran kooperatif, yaitu: a) model Student Teams Achievement Division (STAD), b) Model Jigsaw, c) Investigasi Kelompok (Group Investigation), d) Model Make a 
Match (Membuat Pasangan), e) Model TGT (Teams Games Tournaments) dan f) Model Struktural. Menurut Huda (2011:149) bahwa salah satu model pembelajaran kooperatif yang dapat diterapkan untuk beberapa mata pelajaran seperti ilmu pengetahuan alam, ilmu pengetahuan sosial, matematika, agama dan bahasa adalah model jigsaw. Dalam teknik jigsaw, guru harus dapat memahami kemampuan dan pengalaman siswa dan membantu siswa mengaktifkan skema ini agar materi pelajaran menjadi lebih bermakna. Dalam teknik jigsaw juga siswa diberi banyak kesempatan untuk mengolah informasi dan meningkatkan keterampilan berkomunikasi. Selain itu, teknik jigsaw cocok untuk semua tingkatan kelas.

Demikian halnya dengan kegiatan belajar mengajar Pendidikan Agama Kristen di sekolah, diperlukan sekali kreativitas belajar siswa supaya kegiatan belajar tidak membosankan. Untuk meningkatkan kreativitas belajar siswa tersebut, maka guru Pendidikan Agama Kristen harus meningkatkan kemampuannya dalam menerapkan model pembelajaran kreatif salah satunya adalah menerapkan model jigsaw. Sebagaimana dikemukakan oleh Rusman (2010:218) bahwa dalam pembelajaran kooperatif Jigsaw ini siswa memiliki banyak kesempatan untuk mengemukakan pendapat dan mengolah informasi yang didapat dan dapat meningkatkan keterampilan berkomunikasi, anggota kelompok bertanggungjawab terhadap keberhasilan kelompoknya dan ketuntasan bagian materi yang dipelajari dan dapat menyampaikan informasinya kepada kelompok lain.

Siswa di SMP Negeri 3 Sipoholon khususnya siswa kelas VII sebagaimana hasil observasi penulis bahwa siswa tersebut secara keseluruhan belum menunjukkan kreativitas belajar ketika mengikuti kegiatan belajar Pendidikan Agama Kristen di sekolah. Kebanyakan siswa masih dengan cara belajar hanya mendengarkan guru menerangkan, tetapi belum berani untuk mengajukan beberapa pertanyaan jika masih ada yang kurang dipahami dan belum berani juga dalam memberikan jawaban ketika guru mengajukan beberapa pertanyaan. Dalam kegiatan diskusi kelompok, hanya beberapa siswa saja yang aktif memimpin diskusi, aktif memberikan argumen sementara siswa yang lainnya hanya mendengarkan saja tanpa menunjukkan kreativitas dan keaktifan dalam mengikuti diskusi kelompok. Untuk itu, guru Pendidikan Agama Kristen harus mampu mengembangkan kreativitas belajar siswa dengan menyajikan materi pembelajaran dengan beberapa model pembelajaran yang menuntut adanya kerjasama yang baik diantara siswa, 
salah satunya adalah model pembelajaran kooperatif dengan teknik jigsaw.

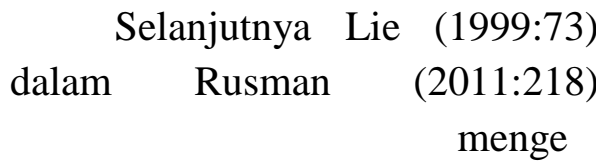

mukakan

bahwapembelajarankooperatif

model jigsaw ini merupakan model belajar kooperatif dengan cara siswa belajar dalam kelompok kecil yang terdiri dari empat sampai enam orang secara heterogen dan siswa bekerja sama saling ketergantungan positif dan bertanggungjawab secara mandiri.

Selanjutnya Sobari (2006:31) menjelaskan pembelajaran model Jigsaw ini dikenal juga dengan kooperatif, karena anggota setiap kelompok dihadapkan pada permasalahan yang berbeda. Tetapi permasalahan yang dihadapi setiap kelompok adalah sama, kita sebut sebagai tim ahli yang bertugas membahas permasalahan yang dihadapi, selanjutnya hasil pembahasan itu di bawa ke kelompok asal dan disampaikan kepada anggota kelompoknya.

Rusman (2011:218) menguraikan langkah- langkah pelaksanaan model pembelajaran Jigsaw adalah sebagai berikut: a) Siswa dikelompokkan dengan anggota \pm 4 orang,

b) Tiap orang dalam tim diberi materi dan tugas yang berbeda, c) Anggota dari tim yang berbeda dengan penugasan yang sama membentuk kelompok baru (kelompok ahli),

d) Setelah kelompok ahli berdiskusi, tiap anggota kembali kekelompok asal dan menjelaskan kepada anggota kelompok tentang sub bab yang mereka kuasai, e) Tiap tim ahli mempresentasikan hasil diskusi, f) Slavin(2010:170) siswa dengan topik-topik ahli yang sama bertemu untuk mendiskusikan topik tersebut, c) Diskusi kelompok; siswa dari kelompok ahli kembali kekelompok asalnya untuk menjelaskan topik yang telah didiskusikanny apada kelompoknya, d) Kuis; siswa memperoleh kuis individu yang mencakup semua topic,

c) Penghargaan kelompok; perhitungan skor kelompok dan menentukan pernghargaan kelompok."

Lebih lanjut Munandar (2009:25) mengemukakan bahwa: "Kreativitas sebagai kemampuan umum untuk menciptakan sesuatu yang baru, sebagai kemampuan untuk memberikan gagasan-gagasan baru yang dapat diterapkan dalam pemecahan masalah, atau sebagai kemampuan untuk melihat hubungan-hubungan baru antara unsurunsur yang sudah ada sebelumnya". Ini menunjukkan bahwa orang yang kreatif 
itu tidak harus menemukan metode baru atau ciptaan baru yang benar-benar baru.

Djamarah

"Pembelajaran kreatif adalah pembelajaran yang mampu menciptakan siswa lebih aktif, berani menyampaikan pendapat dan berargumen, menyampaikan masalah atau solusinya serta memberdayakan semua potensi yang tersedia”.

Beberapa bentuk perilaku kreatifitas siswa dalam mengikuti proses belajar mengajar di kelas, menurut Munandar (2009:35) ditandai dengan: a) Mengajukan pertanyaan, memberikan kritik, tanggapan dan menjawab yang tepat pertanyaan yang diajukan oleh guru ataupun yang diajukan teman-temannya. Siswa yang sering mengajukan pertanyaan sehubungan dengan pelajaran yang diterimanya, karena didasari oleh rasa ingin tahu atau untuk memperjelas apa yang belum dimengertinya dengan demikian siswa memberi kritik dan tanggapan serta menjawab pertanyaan dari bahan pelajaran yang kurang dimengerti dan agak membingungkan, b) Berani dan bebas mengemukakan pendapat atau ide dan mengerjakan sendiri tugas- tugasnya, c) Menciptakan situasi baru, memberikan gagasan baru, memberikan gagasan/usul, mengajukan beberapa alternatif yang tepat dalam pemecahan masalah. Menciptakan situasi ke arah yang meyenangkan. Misalnya jika terjadi sesuatu kekacauan di dalam kelas, siswa kreatif berusaha mengatasi kekacuan tersebut sehingga tercipta situasi yang baru yaitu situasi yang tenang.

Sejalan dengan ini, Jauhari (2011:162-163) mengatakan sebagai berikut: Pembelajaran Kreatif dimaksudkan sebagai berikut:

Di satu sisi, guru bertindak kreatif dalam arti: a) Mengembangkan kegiatan pembelajaran yang beragam, b) Membuat alat bantu belajar yang berguna meskipun sederhana, c) Di sisi lain, siswa pun kreatif dalam hal, d) Merancang/membuat sesuatu, e) Menulis/mengarang.

Menurut Mulyasa (2009:169): "Kreativitas peserta didik dalam belajar sangat bergantung pada kreativitas guru dalam mengemangkan materi standar, dan menciptakan lingkungan belajar yang kondusif dengan berbagai pendekatan dalam meningkatkan kreativitas peserta didik." Dalam Penelitian Tindakan Kelas (PTK), guru dapat meningkatkan kinerjanya secara terus menerus, dengan cara melakukan refleksi diri (self reflection), yakni upaya menganalisis untuk menemukan kelemahan- kelemahan dalam proses pembelajaran yang dilakukannya, kemudian merencanakan untuk proses perbaikan serta mengimplementasikannya dalam proses pembelajaran sesuai dengan program pembelajaran yang telah disusun. Dalam hal ini guru harus kreatif dalam memilih serta mengembangkan materi standar untuk membentuk kompetensi 
peserta didik. Guru harus merangsang kegiatan pembelajaran yang menyebabkan siswa belajar secara aktif, kreatif, inovatif dan menyenangkan. Hasil akhir dari kreativitas itu memuat karya peserta didik dalam ruangan kelas dengan meningkatkan minat dan motivasi peserta didik untuk meningkatkan kreativitas masing-masing. Demikian guru PAK harus mampu menempatkan kehadiran dan fungsinya sebagai pelaksana kurikulum, yang bertujuan untuk mencapai nilai-nilai Kristiani. Sesuai dengan pemahaman tingkat kemampuan serta daya kreativitas belajar PAK siswa.

Siswa yang memiliki kreativitas belajar cenderung akan belajar secara kreatif. Siswa yang belajar kreatif dapat dikenal dengan ciri-ciri kreatif yang ditunjukkanya. Ciri-ciri kreatif mencakup aspek kognitif (berpikir), afektif (sikap dan perasaan) serta keterampilan. Berkenaan dengan peserta didik yang kreatif Mulyasa (2009:164-165) mengemukakan sebagai berikut: Peserta didik yang kreatif jika: a) Dikembangkan rasa percaya diri pada peserta didik, dan tidak ada perasaan takut, b) Diberi kesempatan untuk berkomunikasi ilmiah secara bebas dan

terarah, c) Dilibatkan dalam menentukan tujuan dan evaluasi belajar, d) Diberikan pengawasan yang tidak terlalu ketat dan tidak otoriter, e) Dilibatkan secara aktif dan kreatif dalam proses pembelajaran secara keseluruhan.
Selanjutnya Ibrahim (2005:71) mengemukakan bahwa ciri-ciri siswa yang kreatif sebagai berikut:

1) Rasa ingin tahu yang luas dan mendalam,

2) Sering mengajukan pertanyaan yang banyak,

3) Memberikan banyak gagasan dan usul terhadap suatu masalah,

4) Bebas dalam menyatakan pendapat,

5) Mempunyai rasa keindahan,

6) Mempunyai pendapat sendiri dan dapat mengungkapkannya, tidak mudah terpengaruh orang lain,

7) Rasa humor tinggi,

8) Mempunyai daya imajinasi,

9) Keasliaan (orisinalitas) tinggi, tampak dalam ungkapan gagasan karangan dan sebagainya, dalam pemecahan masalah menggunakan cara-cara orsinil yang jarang diperhatikan orang lain,

10) Dapat bekerja sendiri,

11) Senang mencoba hal-hal yang baru.

\section{METODE}

Alasan penulis memilih sekolah ini menjadi tempat penelitian adalah karena kreativitas belajar siswa belum tinggi dan model pembelajaran jigsaw 
diterapkan untuk meningkatkan Kreativitas belajar siswa. Dalam PTK ini yang menjadi subjek penelitian adalah siswa kelas VII SMP Negeri 3 Sipoholon yang terdiri dari 112 orang . Sampel penelitian ditetapkan 25\% dari jumlah populasi yaitu 112 orang $\mathrm{x} 20 \%$ $=22,4=23$ orang.

Menurut Kunandar (2011: 281): Prosedur penelitian ini terdiri atas 3 siklus yaitu:

1. Siklus 1 PTK untuk Kelas VII Meliputi kegiatan:

a. Perencanaan adalah persiapan yang dilakukan untuk pelaksanaan PTK, antara lain sebagai berikut: 1) Tim peneliti melakukan analisis kurikulum untuk mengetahui kompetensi dasar yang akan disampaikan kepada siswa. Adapun Kompetensi Dasar untuk Siklus I sesuai Rencana Pelaksanaan Pembelajaran (RPP) Kelas VII SMP Negeri 3 Sipoholon, Kecamatan Sipoholon Kab. Taput Tahun pembelajaran 2017/2018 yaitu "Pemeliharaan Ciptaan Allah Secara Bertanggung jawab". 2) Membuat rencana pelaksanaan pembelajaran. 3) Kegiatan Langkah-langkah Strategi Pembelajaran Inkuiri yaitu: a) Orientasi, Langkah orientasi adalah langkah untuk membin asuasana atau iklim pembelajaran yang responsif. b) Merumuskan Masalah, Merumuskan masalah merupakan langkah membawa siswa pada suatu persoalan yang mengadung teka-teki. Persoalan yang disajikan adalah persoalan yang menantang siswa untuk berpikir memecahkan masalah teka-teki. c) Merumuskan hipotesis, Perkiraan sebagai hipotesis bukan sembarang perkiraan, tetapi harus memiliki landasan berpikir yang kokoh, sehingga hipotesis yang dimunculkan itu bersifat rasional dan logis. d) Mengumpulkan data, dalam strategi pembelajaran inkuiri, mengumpulkan data proses yang sangat penting dalam pengembangan intelektual. e) Menguji hipotesis, Mengujihi potesisa dalah proses menentukan jawaban yang dianggap diterima sesuai dengan informasi yang diperoleh berdasarkan pengumpulan data. f) Merumuskan kesimpulan, Merumuskan kesimpulan adalah proses mendeskripsikan temuan yang diperoleh berdasarkan hasil pengujian hipotesis. 4. Membuat instrumen yang digunakan dalam siklus PTK. Meliputi kegiatan: a) Instrumen Penilaian, b) Pelaksanaan Tindakan yaitu deskripsi tindakan yang akan dilakukan, skenario kerja tindakan perbaikan yang akan dikerjakan dan prosedur tindakan yang akan diterapkan. c) Pengamatan atau observasi yaitu prosedur 
perekaman data mengenai proses dan produk dari implementasi tindakan yang dirancang. Penggunaan instrumen yang telah disiapkan sebelumnya perlu diungkap secara rinci dan lugas termasuk cara perekamannya. d) Analisis dan refleksi, Berupa uraian tentang prosedur analisis terhadap hasil pemantauan dan refleksi berkaitan dengan proses dan dampak tindakan perbaikan yang dilaksanakan serta kriteria dan rencana bagi tindakan siklus berikutnya.

2. Siklus 2 PTK Untuk Kelas VII: Meliputi kegiatan: a) Perencanaan,

Tim peneliti membuat rencana pembelajaran berdasarkan hasil refleksi pada siklus pertama. Adapun Kompetensi Dasar untuk Siklus II sesuai Rencana Pelaksanaan Pembelajaran (RPP) Kelas VII SMP Negeri 3 Sipoholon, Kecamatan Sipoholon T.P 2017/2018 yaitu "Pemeliharaan Ciptaan Allah Secara Bertanggungjawab".

Pelaksanaan, Guru melaksanakan pembelajaran berdasarkan rencana pembelajaran hasil refleksi pada siklus pertama. c) Pengamatan, Tim peneliti guru melakukan pengamatan terhadap aktivitas pembelajaran. d) Refleksi, Tim peneliti melakukan refleksi terhadap pelaksanaan siklus kedua dan menyusun rencana untuk siklus ketiga.

3. Siklus 3 PTK Untuk Kelas VII Meliputi kegiatan: Perencanaan, Tim peneliti membuat rencana pembelajaran berdasarkan hasil refleksi pada siklus kedua. Adapun Kompetensi Dasar untuk Siklus III sesuai Rencana Pelaksanaan Pembelajaran (RPP) Kelas VII SMP Negeri 3 Sipoholon, Kecamatan Sipoholon T.P 2017/2018 yaitu "Manusia Diberi Mandat Untuk Berkarya". b) Pelaksanaan, Guru melaksanakan pembelajaran berdasarkan rencana pembelajaran hasil refleksi pada siklus kedua. c) Pengamatan, Tim peneliti melakukan pengamatan terhadap aktivitas pembelajaran. d) Refleksi, Tim peneliti melakukan refleksi terhadap pelaksanaan siklus ketiga dan menganalisis serta membuat kesimpulan atas pelaksanaan pembelajaran yang telah direncanakan dengan melaksanakan tindakan.

\section{HASIL}

Hasil penelitian terhadap
observasi kreativitas belajar
selama kegiatan
pembelajaran PAK melalui
model penerapan 
berlangsung meningkat dari siklus I ke siklus II sampai ke siklus III, hal ini terlihat dari upaya guru PAK dalam meningkatkan kreativitas belajar siswa semakin meningkat dari respon siswa ketika belajar yang memberikan antusiasme dan respon yang baik.

Kreativitas belajar siswa pada siklus I masih terdapat dalam kategori sangat lemah. Tetapi pada siklus II kreativitas belajar siswa sudah masuk ke dalam kategori cukup dan terjadi peningkatan dari siklus I $(26,96 \%)$ ke siklus II $(64,35 \%)$ dengan tingkat keberhasilan mencapai 37,39\%. Siklus III termasuk pada kategori kuat, pada siklus III terjadi peningkatan dari siklus II $(64,35 \%)$ ke siklus III $(80,87 \%)$ dengan tingkat keberhasilan mencapai 16,52\%. Dengan demikian pembelajaran pada siklus I, II dan III dinyatakan berhasil. Berdasarkan pada kelompok responden, maka kreativitas belajar siswa kelas VII SMP Negeri 3 Sipoholon dapat dilihat diketahui: bahwa kreativitas belajar siswa mengalami peningkatan dari siklus I ke siklus II ke siklus III.

Maka dapat disimpulkan bahwa kreativitas belajar PAK siswa kelas VII SMP Negeri 3 Sipoholon, Kecamatan Sipoholon Kab. Taput Tahun pembelajaran2017/2018 memperoleh peningkatan.Hasil observasi penerapan model pembelajaran jigsaw oleh guru PAK dapat diketahui: bahwa penerapan model pembelajaran jigsaw oleh guru
PAK pada siklus I masih dalam kategori cukup. Tetapi pada siklus II penerapan model pembelajaran jigsaw sudah masuk dalam kategori kuat dan terjadi peningkatan dari siklus I $(64 \%)$ ke siklus II (80\%) dengan tingkat keberhasilan $16 \%$.

Siklus III termasuk dalam kategori kuat, dan pada siklus III terjadi peningkatan dari siklus II (80\%) ke siklus III $(96 \%)$ dengan tingkat keberhasilan mencapai (16\%). Dengan demikian penerapan model pembelajaran jigsaw oleh guru PAK dalam upaya meningkatkan kreativitas belajar siswa kelas VII SMP Negeri3 Sipoholon, Kecamatan Sipoholon T.P 2017/2018 dinyatakan meningkat.

\section{KESIMPULAN}

Implementasi Model Pembelajaran Kooperatif Jigsaw oleh Guru PAK Untuk Meningkatkan Kreativitas Belajar Siswa kelas VII SMP Negeri 3 Sipoholon, Kecamatan Sipoholon T.P 2017/2018. Hal ini dapat dibuktikan karena terjadi peningkatan dari siklus I ke siklus II, dan dari siklus II ke Siklus III. Pada saat pelaksanaan siklus I, kreativitas belajar siswa sebesar 26,96\%, pada siklus II perolehan kreativitas belajar siswa meningkat menjadi $64,35 \%$, pada siklus III meningkat lagi menjadi $80,87 \%$. Implementasi dalam penelitian ini ialah bahawa siswa harus tetap mempertahankan kreatifitas belajarnya dan selalu berusaha untuk lebih baik lagi dalam belajar agar semakin hari smakin 
meningkat dalam kreatifitasnya.

\section{DAFTAR PUSTAKA}

Agus Sujanto, Psikologi Umum Jakarta:

Bumi Aksara. Alkitab. 2002. LAI. Jakarta.

Boehlke, R. Robert. 1990. Sejarah Perkembangan Pikiran dan Praktek Pendidikan Agama Kristen : dari Plato sampai IG. Loyola. Jakarta: BPK Gunung Mulia.

Dalyono. 2005. Psikologi Pendidikan. Jakarta: Rineka Cipta.

Djamarah, Syaiful Bahri. 2006. Strategi Belajar Mengajar. Jakarta: Rineka Cipta.

Khairani. 2013. Psikologi Belajar. Yogyakarta: Aswaja Pressindo.

Kristanto. 2006. Prinsip dan Praktik Pendidikan Agama Kristen. Yogyakarta: Andi.

Kunandar.2011. Langkah Mudah
Penelitian Tindakan
Sebagai
Pengembangan Profesi Guru.
Jakarta: PT. Raja Grafindo
Persada.

Kunandar.2011. Penelitian Tindakan
Kelas.

Jakarta: Grafindo Persada

Nainggolan, M. Jhon. 2010. Guru Agama Kristen Sebagai Panggilan dan Profesi. Bandung: Anggota IKAPI Jabar. Muhibbin, Syah. 2010. Psikologi Pendidikan dengan Pendekatan Baru.Bandung: PT Remaja Rosdakarya.

Nasution.2009. Asas-asas Kurikulum. Jakarta: Bumi Aksara.

Poerwadarminta, W.J.S. 1986. Катиs Umum Bahasa Indonesia. Jakarta: Balai Pustaka.

$\overline{\text { Pembelajaran }}^{2009 .}$ Strategi

Purwanto, Ngalim. 2004.Psikologi Pendidikan. Bandung: PT Remaja Rosdakarya.

Riduwan. 2010. Belajar Mudah Penelitian untuk Guru Karyawan dan Peneliti Pemula. Bandung: Alfabeta.

Roestiyah. 2008. Strategi Belajar Mengajar. Jakarta: Rineka Cipta.

Sanjaya, Wina. 2001. Penelitian Tindakan Kelas. Jakarta: Prenada Media Group.

Sardiman, A.M. 2011. Interaksi dan 
Motivasi Belajar Mengajar.

Jakarta: Raja Grafindo Persada.

Silitonga, SAM. 2009. Missiologi, Alkitabiah dan Pendidikan. Medan: CV. Cipta Sarana Mandiri.

Slameto. 2010. Strategi Pembelajaran Berorientasi Standar Proses Pendidikan. Jakarta: Kencana. 